\title{
THE EFFECT OF BRAIN BASED LEARNING MODEL ON STUDENT'S HIGH ORDER THINKING SKILLS
}

\author{
Via Yustitia ${ }^{1}$, Imas Srinana Wardani, Triman Juniarso \\ Universitas PGRI Adi Buana
}

\begin{abstract}
This research aims to determine differences in student's high order thinking skills taught by brain based learning model with student's high order thinking skills taught by direct learning model. The study was conducted through a quasi-experimental posttest design. The population of this study was students of the elementary school teacher education department of Adi Buana PGRI University of Surabaya, by using Random Sampling. The subjects are 80 students inclasses 2017-A and 2017-B. The data was collected by using test method. The data analyses were T test the difference of average, to examine the distinction of high order thinking skills between the brain based learning and direct learning class. The result of the study showed that score average of the student's high order thinking skills in brain based learning classwere better than score average of of the student's high order thinking skills in direct learning class.
\end{abstract}

Keyword: Brain based learning, High order thinking skills

\begin{abstract}
Abstrak: Penelitian ini bertujuan untuk mengetahui perbedaan keterampilan berpikir tingkat tinggi siswa yang diajarkan oleh model pembelajaran berbasis otak dengan keterampilan berpikir tingkat tinggi siswa yang diajarkan oleh model pembelajaran langsung. Penelitian ini dilakukan melalui desain posttest kuasi-eksperimental. Populasi penelitian ini adalah siswa jurusan pendidikan guru sekolah dasar Universitas Adi Buana PGRI Surabaya, dengan menggunakan Random Sampling. Subjek penelitian ini adalah 80 siswa yang mencakup 2017-A dan 2017-B. Data dikumpulkan dengan menggunakan metode tes. Analisis data adalah uji T perbedaan rata-rata, untuk menguji perbedaan keterampilan berpikir tingkat tinggi antara pembelajaran berbasis otak dan kelas pembelajaran langsung. Hasil penelitian menunjukkan bahwa skor rata-rata keterampilan berpikir tingkat tinggi siswa di kelas pembelajaran berbasis otak lebih baik daripada skor rata-rata keterampilan berpikir tingkat tinggi siswa di kelas pembelajaran langsung.
\end{abstract}

Kata kunci: Pembelajaran Berbasis Otak, Keterampilan Berpikir Tingkat Tinggi

\section{INTRODUCTION}

The National Research Council (Lindquist, 1989) describes HOT as a thinking that involves: problem solving where multiple solutions are possible, paths of action for solving problem that are not specified in advance (creative problem solving), considerable mental energy directed toward problem solving, subtle less than obvious decisions about strategies, transferable some criteria to the problem solving process, problems that do not provide a clear starting point, some degree of metacognition and self awareness, development and application of new theories onto sets of facts and problems. As Resnick in 2010 said, "scaling up the 'thinking curriculum' in a way that will foster proficiency for all students is currently a major educational challenge" (as cited in Zohar, 2013, p. 234).

We should manage HOT skills in the classroom teaching learning process because they have enormous benefits for learners (Mainali, 2012). One study made by the Carnegie Institute in America stated that $99 \%$ of people the ones who succeed in their lives are people who use $80 \%$ of their brains to creative ability and thinking and can apply their knowledge well (Faidi, 33: 2013). The lecturer should be able to make the students alter the pattern of

\footnotetext{
' Universitas PGRI Adi Buana, Surabaya, Indanesia. email: via.yustitia国unipasby.ac.id
} 
learning which tend to receive to become more active in learning so that students can use the logic. Lecturers need to pay attention to the model of teaching which is used to achieve the goal of the development of high order thinking skill.

Brain based learning model is an effort-oriented learning model empowering the brain potential of students. Brain based learning (BBL) is learning which is harmonized with the way the brain is naturally designed learn. Mustiada's research (2014) shows that BBL learning model (Brain Based Learning) is very effective to improve science learning achievement results.

Based from the explanation above, this research aims to determine differences in student's high order thinking skills taught by brain based learning model with student's high order thinking skills taught by direct learning model.

\section{LITERATURE REVIEW Brain Based Learning}

Brain Based Learning offers a concept for creating learning by striving to strengthen students' brain potential. Three main strategiescan be developed in the implementation of brain-based learning (Orinaru, 2012). First, create learning environment that challenges students' thinking skills. Both create fun learning environment. Third creates learning active and real for students (active learning). Brain Based Learning appreciate what is natural for the human brain and how the brain by the environment because most of our brains are involved in almost everything learning action (Sapa'at, 2007). Anderson team recognized that knowledge was not really a process, as originally proposed in the taxonomy, but the context in which thinking takes place. It means HOT is important in pedagogical process (cited in Mckeachie \& Svinicki 2006: 320)

\section{High Order Thinking}

HOTS is a thinking process that involves mental activities in an effort to explore complex, reflective, and creative experiences that are carried out consciously to achieve goals, namely acquiring knowledge that includes the level of analytical, synthesis, and evaluative thinking (Wardana, 2010). Higher-order thinking skills, known as High-Level Thingking Skills (Bloom) in Bloom Taxonomy, are sequences of levels (cognitive) from low to high levels. HOT effectively as a matter of fulfilling a national aspiration in education. Teachers have to realize that the effectiveness of teaching HOT will materialize only when the traditional view of transmitting information becomes secondary to a more constructivist view which affords students active learning that harnesses meaning-making in the learning process (Yen \& Halili, 2015).

\section{METHODOLOGY}

This research was quantitative. It was conducted at July 2017. It was held in primary school teacher education department (PGSD) of Adi Buana PGRI University, Surabaya. The population of this study was students of the elementary school teacher education department of University of PGRI Adi Buana Surabaya, by using Cluster Random Sampling. It was divided into two classes, Class 2017 B as the class experiment and Class 2017 B as a class control. The research design this experiment used Quasi Experimental Design with the form of posttest only control design. The design of the experiment can be seen in the table 1 , as follow:

Table.1. The design of experience

\begin{tabular}{llll}
\hline & Group. & Treatment & Posttest \\
\hline Random & Eksperiment & X1 & $\mathrm{T}$ \\
& 1 & & \\
\hline
\end{tabular}


\begin{tabular}{llll}
\hline Random & Eksperiment & $\mathrm{X} 2$ & $\mathrm{~T}$
\end{tabular}

1

The variables used in this research were the dependent variables and independent variables. The independent variable Brain Based Learning model, while the dependent variable was the ability of the high order thinking skills. The data collected by using test method. The data analyses were $\mathrm{T}$ test the difference of average, to examine the distinction of high order thinking skills between the brain based learning and direct learning class.

\section{RESULTS AND DISCUSSION}

According to the data analysis in the early stages with the normality test obtained the normal data. Based on the analysis of the data during the early stages of using the test of homogeneity, and the average similarity tests showed that the class was taken as the samples in research. It had variants homogenous and did not have the average differences. This means that the sample was derived fromthe condition or state of the beginning of the relative is not different from that have the same knowledge.

Brain based learning was applied in a class experiment effectively against the high order thinking skill. Based on the calculation of the average one party similarity tests (test the right) obtained $t$ count $>t$ the table then $\mathrm{H} 0$ rejected, it means that the average ability of the logic of the students of class experiment was better than the class control.

The result of the study showed that score average of the student's high order thinking skills in brain based learning classwere better than score average of of the student's high order thinking skills in direct learning class. This is in line with the results of Ozden \& Gultekin (2008) research shows that BBL learning is proven to be more effective than conventional learning in science lessons in terms of improving student learning outcomes and the students' memory of the acquired knowledge.

Significant difference between students who use learning with the BBL learning model (Brain Based Learning and students use learning with models conventional learning is caused because of differences in treatment on learning and process steps delivery of material. There are 3 steps in BBL learning process (Brain Based Learning) with steps as following. 1) creating a learning environment which challenges students' thinking skills, 2) creating a learning environment fun, 3) creating a situation active and meaningful learning for students. Student activity in the implementation of learning on the concept of using mathematics lessons Brain Based Learning model which includes aspects of self, accuracy and partnership.

\section{CONCLUSION}

By the results of this study, it can presented as follows. 1) To students, in order using math learning BBL learning model (Brain Based Learning) because it can improve learning outcomes and realize independence. 2) to lecturers, especially who teach mathematics in the process learning to use the model BBL (Brain Based Learning) learning as one of the alternative to improve high order thinking skills.

\section{REFERENCES}

Faidi, Ahmad. (2013). Tutorial Mengajar Untuk Melejitkan Otak kiri dan Kanan Anak. Yogjakarta: Diva Press.

Lindquist, M. M. (1989). Results from the Fourth Mathematics Assessment of the National Assessment of Educational Progress. National Council of Teachers of Mathematics, 1906 Association Drive, Reston, VA 22091. 
Mainali, P,B. (2012). Higher Order Thinking In Education. Academic Voices A Multidisciplinary Journal, 2(1), 5-10.

McKeachie, W. J., \& Svinicki, M. (2006). McKeachie's teaching tips: Strategies, research, and theory for college and university teachers.

Munir. (2013). Multimedia. Bandung: Alfabeta.

Mustiada, I. G. A. M., Agung, A. A. G., \& Antari, N. N. M. (2014). Pengaruh model pembelajaran BBL (brain based learning) bermuatan karakter terhadap hasil belajar IPA. MIMBAR PGSD Undiksha, 2(1).

Orinaru. (2012). Penerapan

\begin{tabular}{lrr} 
Pendekatan & Brain & Based \\
Learning & $($ BBL $)$ & dalam \\
pembelajaran & Matematika di \\
Sekolah & \multicolumn{2}{r}{ Dasar }
\end{tabular}

(Online).(http://orinaru.wordpress.c om/2012/09/20/penerapan-

pendekatan-brain-basedlearning-

bbl-dalam-pembelajaran-

matematika-di-sekolah-dasar/,

Diakses tanggal 28 Januari 2017 pukul 15.30).

Ozden,M \& Gultekin M. (2008). The effects of BBL on academic achievements and retention of knowladge in science course. EJSE. vol 12 , no 1 .

Resnick, L. B. (2010). Nested learning systems for the thinking curriculum. Educational researcher, 39(3), 183-197.

Rogers, Y., \& Scaife, M. (1998). How Can Interactive Multimedi Facillite Learning?

Rohmadi, Muhammad dan Lili Hartono. (2011). Kajian Bahasa, Sastra, dan Budaya Jawa Teori dan Pembelajarannya (Study of Javanese Language, Literature, Culture: Theory and Learning). Surakarta: Pelangi Press.

Sapa'at, A. (2007). Brain Based Learning. Online), (http://matematika.upi.edu/index.ph p/brain- based-learning), Diakses Tanggal 10 April 2014.

Wardana, N. (2010). Pengaruh Model Pembelajaran Berbasis Masalah Terhadap Kemampuan Berpikir Tingkat Tinggi dan Pemahaman Konsep Fisika. Diperoleh 28 Januari 2014 dari http://jurnal.pdii.lipi.go.id/admin/ju $\mathrm{rnal} / 621016251635.858-4543 . \mathrm{pdf}$

Yen, T. S., \& Halili, S. H. (2015). Effective teaching of higher order thinking (HOT) in education. The Online Journal of Distance Education and e-Learning, 3(2), 4147.

Zohar, A. (2013). Challenges in wide scale implementation efforts to foster higher order thinking (HOT) in science education across a whole wide system. Thinking Skills and Creativity, 10, 233-249. 